\title{
Vuoden 2019 viimeisen Avaimen teemana matkakirjallisuus
}

Numerossa 4/2019 pureudutaan matkakirjallisuuden tutkimuksen moninaiseen kenttään. Tutkimusala tarjoaa tärkeitä näkökulmia esimerkiksi siihen, miten subjektiivista kokemusta, tilaa ja paikkaa, identiteettejä, vierauden kohtaamista ja kulttuurista vuorovaikutusta voidaan esittää kirjallisuuden keinoin. Matkakirjallisuutta tutkittiin aiemmin paljolti historiallisena, maantieteellisenä ja antropologisena aineistona, mutta tutkimusalan vakiinnuttua huomiota on alettu kiinnittää myös matkakirjallisuuden poetiikkaan, muotoihin ja teemoihin. Tällä hetkellä aiheen kansainvälinen tutkimus on vilkasta, monipuolista ja tieteidenvälistä. Alan vakiintuneisuudesta kertovat muun muassa säännöllisesti ilmestyvät tieteelliset lehdet ja julkaisusarjat sekä yliopistollinen opetus ja kansainväliset konferenssit.

Avaimen teemanumerossa esitellään tuoretta suomalaista matkakirjallisuuden tutkimusta. Numeron artikkelit ja katsaukset kattavat laajan valikoiman kielialueita ja historiallisia aikakausia. Huomio kiinnittyy muun muassa kuvallisuuteen, monikielisyyteen, tilan kysymyksiin, tosiperäisen esityksen ja fiktion suhteeseen sekä matkakirjallisuuden historiaan. Esiin nousevat myös kysymykset matkakirjallisten lajien määrittelystä. Missä määrin lajia määrittävät tietyt tekstin piirteet tai lukijan odotukset ja missä määrin taas yhteys matkan kokemukseen?

Jos haluat tarjota artikkelia tai muuta kirjoitusta (essee, katsaus, kirja-arvio, konferenssiraportti tms.), ota yhteyttä teemanumeron päätoimittajiin.

Lisätietoja numeron päätoimittajilta:

Kai Mikkonen (kai.mikkonen@helsinki.fi)

Ilona Lindh (ilona.lindh@helsinki.fi) 